(c) The Author(s), 2021. Published by Cambridge University Press. This is an Open Access article, distributed under the terms of the Creative Commons Attribution licence (http://creativecommons.org/licenses/by/4.0/), which permits unrestricted re-use, distribution, and reproduction in any medium, provided the original work is properly cited. doi:10.1017/S1474746421000191

\title{
Equality and Devolution in the United Kingdom: A Story in Three Acts and a Sequel
}

\author{
Paula Devine*, Grace Kelly** and Martina McAuley*** \\ *School of Social Sciences, Education and Social Work, Queen's University Belfast, UK \\ E-mail: p.devine@qub.ac.uk \\ ${ }^{* *}$ School of Social Sciences, Education and Social Work, Queen's University Belfast, UK \\ E-mail: g.p.kelly@qub.ac.uk \\ ***Housing Rights, Belfast, UK \\ E-mail: martina@housingrights.org.uk
}

Within the United Kingdom (UK), many of the arguments driving devolution and Brexit focused on equality. This article assesses how notions of equality have been shaped over the past two decades. Using a chronology of theoretical, political and public interpretations of equality between 1998 and 2018, the article highlights the shifting positions of Northern Ireland (NI) and the rest of the UK. NI once led the way in relation to equality legislation, and equality was the cornerstone of the Good Friday/Belfast peace agreement. However, the Equality Act 2010 in Great Britain meant that NI was left behind. The nature of future UK/EU relationships and how these might influence the direction and extent of the equality debate in the UK is unclear. While this article focuses on the UK, the questions that it raises have global application, due to the international influences on equality discourse and legislation.

Keywords: equality, devolution, Brexit, United Kingdom, Northern Ireland.

\section{Introduction}

January 2020 marked a pivotal point for the United Kingdom (UK) as it left the European Union (EU) - also known as Brexit. During the same month, devolution was fully restored in Northern Ireland (NI), with the reinstatement of the NI Assembly and Executive after a threeyear suspension. Devolution has been a key feature within the UK since 1998, with the establishment of the Scottish Parliament, National Assembly for Wales and the NI Assembly. Many of the arguments driving devolution and Brexit focused on equality. For example, Chaney (2011: 432) argues that devolution has effectively 'constitutionalized' the promotion of equality in relation to a range of social policy functions. For those in support of Brexit, the vote to leave is said to be a vote for equality in relation to self-determination (GormleyHeenan and Aughey, 2017), or a protest vote as a result of discontent at social, economic and educational inequality, intensified by lack of opportunity (Goodwin and Heath, 2016). Other analyses contradicted the focus on group differences, arguing that pro-Brexit views were more likely to be affected by individual attitudes and personality, with those disliking moral and ethnic diversity being more inclined to support 'leave' and those inclined towards openness and cultural equality being more likely to back 'remain' (Kaufmann, 2016). 
If processes of devolution can be understood as an expression of attitudes towards equality, then it is timely to take stock of how those notions of equality have been shaped over the past two decades. We do this using a chronology of theoretical, political and public interpretations of equality across the UK between 1998 and 2018, examining the interplay between these differing perspectives and the evolving shape of UK devolution. In particular, the article highlights the shifting positions of NI and Great Britain $(\mathrm{GB})^{1}$ in regards to equality legislation. This is set against a backdrop of uncertainties surrounding future UK/EU relationships and how these might influence the future direction and extent of the equality debate. While this article focuses on the UK, the questions that it brings forth have global application, not least because of the international influences - and from the EU in particular - on equality discourse and legislation.

\section{What is equality?}

Equality is a complex and contested concept, often determined by one's political affiliation and general fundamental outlook on life and society (Bagilhole, 2009). The UN Declaration of Human Rights (1948, Article One) states that 'All human beings are born free and equal in dignity and rights' and as such is referring to individual people. Nevertheless, equality is often thought of in terms of groups of people. Sen (1982) asks an important question in terms of 'equality of what?', which Baker et al. (2004) suggest could be answered by three types of equality: basic equality, equality of opportunity, and equality of condition or outcome. A modest interpretation suggests that, while conceptual definitions of equality may differ, equality emerges along a continuum, with basic equality and substantial equality at either end.

Basic equality is considered the 'cornerstone of egalitarian thinking' and rests on the assumption that all human beings are equally worthy of concern and respect and have equal worth and importance (ibid: 23). The guiding tenet is support for a set of basic standards, capable of meeting absolute minimum human needs - the need for food, water, clothing, shelter and safety from injury or harm.

Moving along the continuum towards a more liberal notion of equality is the idea of equality of opportunity. This acknowledges that in life, there will always be people with access to more resources than others (e.g. access to better employment, housing, education, health), but at the same time recognising that inequalities need to be balanced with fairness so that everyone has the same chance to compete for resources and enjoy equal and democratic rights to do so. This requires establishing a set of minimum standards to which everyone is entitled, a cut-off point or safety net below which no one should fall, and consolidating this with a structure to oversee fair competition for resources over and above this set minimum (Rawls, 1971, 1999).

Exactly how far equality of opportunity is from basic equality on the continuum is difficult to determine because of the lack of agreement on what those minimum standards should be. A good example is the dichotomy between absolute and relative poverty, where absolute poverty is understood as lacking sufficient income to meet basic physical needs: 'A family is poor if it cannot afford to eat' (Joseph and Sumption, 1979: 27). In contrast, relative poverty is understood in broader terms than simply lack of income, being identified as exclusion from a minimally accepted way of life relative to the society to which a person belongs (Townsend, 1979). 
Further along the continuum, equality of outcome or condition places the focus on the social structure and is regarded as a more radical approach to equality issues (Marshall, 1994). Equality of condition calls for the acceptance of diversity in addition to respect and recognition; a more substantial equality of resources aimed at enabling roughly equal prospects of well-being; power relations which aim to extend democracy and provide stronger, more participatory politics ${ }^{2}$; and educational and occupational options that give everyone the prospect of self-development and satisfying work. Equality of outcome is perhaps the most contested approach. Parekh (1992) advocated the idea of 'preferential treatment' for disadvantaged groups in addressing inequalities, whilst Cunningham (1992: 178) stressed that such an approach would require 'considerable intrusion on individual liberty' and would be 'impossible to enforce'.

Most approaches to equality legislation within the UK utilise the concept of equality of opportunity. Bagilhole (2009) argues that the term equal opportunity was based on a now-disputed premise of treating everyone the same, whereas she argues for the use of the term 'equal opportunity and diversity' - a more sophisticated coupling which emphasises the recognition of difference and the possibility of 'multiple disadvantage' where disadvantage is not cumulative but intersectional.

Equal opportunity and diversity in the UK since the mid-20th century can be traced through distinct eras (ibid) with differing driving forces from the moral concerns of the post-World War Two era to the political, economic and professional interests of the New Labour era (which ran from 1997 to 2010, under Prime Ministers Tony Blair and Gordon Brown). Underpinning these changes were dynamic social movements such as the civil rights movement, women's movement, disability rights movement and various campaigns for rights and recognition which acted as driving forces alongside international influences. Throughout that time, there was a raft of prominent equality legislation (for example, the Disability Discrimination Act 1995). Some of this applied throughout the UK, whilst others applied to specific regions (usually GB only or NI only).

\section{Setting the scene: 1998 and devolution}

1998 saw the beginning of devolution in the UK, with the signing of the NI Act, the Scotland Act and the Government of Wales Act. This resulted in different legislative contexts, and slightly different powers across the three devolved nations. The Scottish Parliament has the largest set of devolved powers, including some authority on income tax and benefits, and where distinctive policy changes have been viewed as demonstrating political commitment to social justice and equality (Mooney and Scott, 2016). However, not all issues are devolved from the UK Parliament in Westminster (such as the constitution, defence, national security, immigration and citizenship, and some tax policy).

The devolution of responsibility for equality to $\mathrm{NI}$ in 1998 initially led to stronger provision in NI than other parts of the UK (Harvey and Spencer, 2011). Drawing on the best international and European practice, the Good Friday/Belfast Agreement emphasised equality and human rights as a central element of building lasting peace in the region (McCrudden, 1998). Equality obligations that were incorporated into the Agreement were legally implemented by the NI Act 1998. Of particular significance is Section 75 (S75) of that Act, which specified statutory obligations on public bodies in NI to promote equality of opportunity and good relations on nine grounds: religious belief; political opinion; gender; race and ethnicity; age; sexual orientation; disability; marital status and those with 
dependents. At that time, S75 represented the most extensive positive equality duty in the UK (O'Cinneide, 2003), and was widely applauded for its constitutional sophistication. Indeed, the Act was heralded as the 'most radical equality legislation in Western Europe' (Donnelly and Osborne 2005: 149). The requirements of S75 were anticipatory and proactive, rather than reactive. Moreover, as well as promoting equality of opportunity, Baker et al. (2004) argued that this could also be adapted to provide equality of condition.

Under the NI Act, a single equality body was established. The Equality Commission for Northern Ireland (ECNI) is an amalgamation of pre-existing powers and roles undertaken by the Commission for Racial Equality for Northern Ireland, the Equal Opportunities Commission for Northern Ireland, the Fair Employment Commission and the Northern Ireland Disability Council. A separate body was established with a remit for human rights, the NI Human Rights Commission (NIHRC). Replacing the Standing Advisory Commission on Human Rights (SACHR), the NIHRC has enhanced powers to advance human rights in a post-conflict context (Harvey and Spencer, 2011), in addition to incorporating the European Convention on Human Rights into domestic law.

The policy imperative for strong equality duty was driven by the $\mathrm{NI}$ conflict: McKittrick and McVea (2010) argued that addressing inequality was essential for creating and maintaining peace in the region. Furthermore, the success in the development of this equality legislation resulted from 'a well-informed and truculent civil society' (McCrudden, 2007: 266). The importance of the requirement for public authorities to consult with representatives of persons likely to be affected by its policies was influential in leading the way for subsequent legislation in the rest of the UK and in constituting the first positive equality duty, as opposed to merely anti-discriminatory duties (McLaughlin, 2007). This will be discussed further below.

In other regions of the UK, equality issues were historically dealt with through Westminster. However, as a result of successful campaigning by equality movements, the Government of Wales Act of 1998 included a specific equality clause. This duty required the Welsh Assembly to be proactive and have due regard to the principles of equality of opportunity for all people in relation to all devolved functions. In Scotland, as a result of pressure from the public and the Scottish Labour Party, the 1998 Scotland Act imposed a duty on the Scottish Parliament to legislate for the inclusion of an equal opportunities clause similar to that in Wales. This meant that the new legislatures of Scotland, Wales and NI were placed under equality laws which required a proactive stance from government and the promotion of equal opportunities in public authorities (Mackay and Bilton, 2000).

\section{Act one: The Race Relations (Amendment) Act 2000}

The NI Act set an important context for the Race Relations (Amendment) Act 2000 (Conley and Wright, 2015), given the shift from negative to positive equality duties within S75 (McLaughlin, 2007). Traditionally, equality legislation incorporated negative equality duties, which tackle discrimination by attempts to prevent certain behaviours. By offering redress after the behaviour had occurred, McLaughlin argued that such duties were 'inherently tolerant of discrimination' (ibid: 112), especially as the onus was on the individual or group to take a claim against an organisation for unfair treatment on the grounds of the particular type of discrimination. Thus, anti-discrimination laws were 
reactive rather than proactive, with the remedy often in the form of compensation without any challenge of existing law or practice (Baker et al., 2004).

In contrast, positive equality duties are aimed at preventing and pre-empting inequality and promoting equality, requiring and encouraging preventative behaviour and practice (Fredman, 2002). This should involve consultative policy-making processes (in terms of including those from the groups which may be targeted for unequal treatment). The aim is for the mainstreaming of an equality ethos. McLaughlin (2007) argued that social attitude changes had accompanied the development of positive equality duties in $\mathrm{NI}$, so that although the legislation applied only to public authorities, the effect could be wide ranging. One potential pitfall highlighted by the $\mathrm{NI}$ experience was that public authorities only had to comply with the letter of the law and therefore compliance might be 'thin' (ibid: 119). This relates to the need to show that equality considerations were raised in decision-making processes, rather than showing how the outcome may have been impacted by equality considerations.

Extensive campaigning by family and community groups about the case of Stephen Lawrence (a black teenager who was the victim of racist assault and murder in 1993 in London), and the subsequent Macpherson Inquiry, led to the identification of 'institutional racism'. The Inquiry found that racism extended beyond individual acts and was pervasive among the police making the decisions in the case (Bagilhole, 2009). As a result, it was recognised that there was a need for a new duty on the public sector to promote racial equality, rather than to avoid racial discrimination. Thus, the Race Relations (Amendment) Act 2000 placed new responsibilities on public authorities in GB (but not on the private sector) to promote equal opportunities and good relations between people from different racial groups to promote equality (ibid). This represented the first steps towards positive duties imposed on public authorities in GB (Hepple, 2010).

Nevertheless, despite such moves, NI was still taking the lead in equality policy. Under the Fair Employment and Treatment Northern Ireland Order 1998, there are some additional equality duties imposed on private employers, which do not exist elsewhere in the UK. In NI, all private sector employers with ten or more employees (defined as someone working sixteen hours per week or more) are required to register with the ECNI. Failure to register is a criminal offence. The Order makes discrimination on grounds of religious belief and/or political opinion unlawful.

\section{Act two: an act of union - The Equality Act (2006)}

At the start of the new millennium, New Labour launched a major consultation on a review of equality institutions: 'Equality and diversity: Making it happen' (DTI, 2002). Then Prime Minister, Tony Blair, proclaimed the review to be the 'most significant in over a quarter century' (quoted in Bagilhole, 2009: 130). NI was perhaps assumed to be dealing appropriately with its own equality issues and was not included in the Review. At that time, the establishment of a single equality body in $\mathrm{NI}$ (ECNI) was held as a model for the rest of the UK (Hepple, 2010).

Following this consultation, the government announced its intention to establish a single equality commission in Britain and, in 2003, set up a task force to advise on the role, functions, priorities and activities of a single equality body. The Task Force included representatives from charities, businesses, the Trades Union movement and local 
government and representatives from the three Commissions (Equal Opportunities, Racial Equality and Disability Rights). Representatives from the regional governments of Scotland and Wales were also on the Task Force, but notably absent were representatives from NI. This is perhaps surprising given that the Good Friday/Belfast Agreement and NI Act from 1998 were held as a benchmark, and a single equality body had already been established in NI. The case for equality and human rights was made in economic and moral terms in the White Paper 'Fairness For All: A New Commission for Equality and Human Rights' in 2004:

The Government believes that fairness for all is the basis of a healthy democracy, economic prosperity and the effective delivery of our public services. Equality and human rights matter to all of us, not just those who experience discrimination and unfair treatment (DTI, 2004: 11).

As a result of the institutions review, proposals of the Task Force, as well as new EU directives on age, sexual orientation and religion or belief (Bagilhole, 2009), a new single equality body combined the Equal Opportunities Commission (established by the Sex Discrimination Act 1975), the Commission for Racial Equality (established by the Race Relations Act 1976), and the Disability Rights Commission (established by the Disability Rights Commission Act 1999), thus providing a 'joined-up approach that puts equality in the mainstream of concerns' (DTI, 2003: 1). The response from equality campaigners was largely positive, although there was concern among existing commissions that a single equality act would be needed before such an organisation could be successful (Bagilhole, 2009). This body - the Commission for Equality and Human Rights (CEHR) - eventually became the Equality and Human Rights Commission (EHRC) in 2007. EHRC includes a remit for equality matters for England, Scotland and Wales, but a remit for human rights issues for England and Wales only. Responsibility for equality and human rights remain institutionally separate in $\mathrm{NI}$ and Scotland, reflecting the main influences in the development of equality and human rights law in those jurisdictions (Harvey and Spencer, 2011: 30). These include the emphasis on social justice in Scotland and responses to discrimination and conflict in NI.

The core functions of this body included encouraging awareness and good practice on equality and diversity; promoting equality of opportunity between people in different groups protected by discrimination law; and working towards the elimination of unlawful discrimination and harassment (ibid). However, there was only a light touch to the private sector: this underscored New Labour's approach to private business, which was in keeping with the previous Conservative administrations' free-market ethos. Private companies would not face compulsion but would instead be encouraged to follow new codes of good practice (DTI, 2004).

The Equality Act 2006 was the culmination of four years of consultations and debate on how best to organise and administer the government's human rights legislation and unite the responsibilities of the previous three commissions (Gedalof, 2013: 118). The main purposes were to: formally establish the CEHR; make it unlawful to discriminate on the grounds of religion or belief; provide the power to make regulations that prohibit discrimination on the grounds of sexual orientation; create a duty on public authorities to promote equality of opportunity between women and men ('the gender duty') building on the existing race equality duty (2002) and 
alongside the disability equality duty (2006) and prohibit sex discrimination and harassment in the exercise of public functions.

\section{Situation of Northern Ireland}

Despite being most progressive in 1998, NI started to lag behind in relation to equality legislation at the start of the twenty-first century. Hayward and Mitchell (2003) argue that NI was hampered by the emphasis within Protestantism on individual responsibility for failure and the shared emphasis (along with Conservative thinking) on competition and reward. These were reflected in the principles of unionist parties, and affected their stance on equality legislation and social welfare. This was at odds with the social investment model of New Labour and the European social model in general, which was a philosophical approach closer to that espoused by the nationalist parties in $\mathrm{NI}$, with their endorsement of social rights and social cohesion (Hill et al., 2005).

\section{Social cohesion, dealing with diversity and the business case}

The new millennium also began with disturbances in urban areas of England (Bradford, Burnley and Oldham in 2001) that were suffering the strain of poverty and lack of social cohesion (Home Office, 2001). Thus, New Labour put forward a social cohesion case for equality legislation (Bagilhole, 2009). At the same time the Home Office consultation paper 'Strength in Diversity' (Home Office, 2004) focused on the need to build community cohesion and reduce race inequalities. 'The White Paper on Equality and Human Rights: A new framework for Britain' (DTI and DCA, 2004) pointed to the need to provide the framework for a more cohesive society but also continued to make the business case for equality (inherited from the Conservative government's emphasis on the marketplace and focus on entrepreneurialism in the booming 1990s). Thus, the 1990s and the early years of the twenty-first century saw a move away from the provision of equal opportunities and towards the need for managing diversity (Robertson, 2015). This continued shift towards a business case for equality issues, based on an individualistic approach to managing diversity and building social cohesion, mirrored changes in the economic and political sphere due to the dominance of the neoliberal ideal (Harvey, 2005; Davies, 2017) and the consequent focus on individualism (Harvey, 2005) and personal responsibility (Rose, 1999; Joseph, 2014; Schrecker and Bambra, 2015). A similar shift to diversity management occurred in the United States of America, coinciding with a significant change in the political sphere towards greater deregulation and a more libertarian approach to business in particular (Ozbilgin and Tatli, 2011).

Tatli (2011) argued that this shift to a focus on managing diversity was not completed however, and that at the end of the first decade of the twenty-first century, the private sector was still committed to equal opportunities but was inclined to use the business case as a way to pick and mix their way through equality issues. Thus, by the end of the decade there was no consensus on what equality meant (Tatli and Ozbilgin, 2009). The managing diversity approach has been criticised for being too focused on performance and related primarily to the individual (Brammer et al., 2009; Robertson, 2015), whereas Pringle (2008) argued that an equal opportunities approach was humanitarian-based and took account of social structures. Robertson (2015) also argued that the focus on quantitative data (the metrics related to equality) used in 
the managing diversity approach meant that there was little or no appreciation for the need to change business culture. This focus on quantitative measures was criticised as a 'Noah's Ark approach' (Liswood, 2010).

\section{Act three: The Equality Act to end all equality acts}

In advance of the EU Year of Equal Opportunities for All in 2007, the New Labour government set up an independent, comprehensive review in 2005 of their record on equality after ten years in government chaired by Trevor Phillips. This Equalities Review defined an equal society as one which 'protects and promotes equal, real freedom and substantive opportunity to live in the ways people value and would choose, so that everyone can flourish' (Equalities Review, 2007: 16). Given that the Review specified that the aim of equality should be to 'give everyone an equal chance to contribute' (ibid: 2), then equality of opportunity was clearly the underlying ideological thrust as understood by New Labour.

\section{Calls for a single equality act}

In terms of legislation, the Equalities Review (2007) called for a single equality act to replace the individual pieces of legislation. This was supported by other factors, including an EU Directive in 2000 requiring all member states to ensure that reasonable accommodation obligations would operate in the context of employment in order to protect disabled people from unequal treatment in employment. This reflected the changing definition of disability, from a focus on the individual (a medical model of disability) to a focus on the world around them which represented a barrier to their inclusion (the social model of disability).

\section{A framework for fairness}

The Equalities Review's final report 'Fairness and Freedom: The final report of the Equalities Review' was published in February 2007 (Equalities Review, 2007). The conclusion was one of mixed results. Progress had been made in terms of equality relating to race, age, disability and gender (Hepple, 2010), such as the positive duties imposed on public authorities in the Race Relations (Amendment) Act 2000, the Employment Equality [Age] Regulations 2006, the Disability Equality Duty 2006, the Gender Equality Duty 2007, and the Work and Families Act 2006, as well as the introduction of paid paternity leave. The right to civil partnerships for same sex couples, and the overturning of the infamous Section Twenty-eight of the Local Government Act 1988, which prohibited local authorities in England, Scotland and Wales from intentionally promoting homosexuality, were positive steps. Nevertheless, prejudices were still thought to be engrained, underlined by the failure to extend anti-discrimination measures to the provision of goods and services (DCLG, 2007).

The responses to the Equalities Review were presented for consultation in proposals for an Equality Bill as part of the Green paper 'A Framework for Fairness: Proposals for a Single Equality Bill for Great Britain' in June 2007 (ibid). The government's response to the consultation was set out in the 'Equality Bill: Government response to the consultation', introduced to Parliament in 2008 (Government Equalities Office, 2008). 
Reactions to the proposals were wide-ranging but perhaps unsurprising. The EHRC, former equality commissions, organisations representing interests such as age and sexual orientation and trades unions in general considered that, overall, the proposals could have gone further and therefore lacked ambition. Private sector firms on the other hand generally considered that the proposals struck a sensible balance between the need to avoid disproportionate burdens and the need to modernise discrimination law. Trades unions welcomed the proposal for integration of the three separate Commissions as a way to provide a more effective means of dealing with multiple discrimination. The report highlighted that almost all respondents agreed with the objective of streamlining the law, replacing the current nine major pieces of discrimination legislation and around 100 statutory instruments setting out connected rules and regulations with a new single Equality Act.

There was positive response in favour of extending the Equality Duty to age, sexual orientation and religion/belief, as well as gender reassignment (DCLG, 2007). Opposition to equality with regard to sexual orientation came primarily from religious groups. For example, The Church of England felt that this approach could undermine respect for the equal worth of different groups in the context of faith schools. The concern that same-sex civil partnerships would have to be promoted as equal to marriage was expressed by the Catholic Bishops Conference of England and Wales.

\section{The Equality Act (2010)}

The Equality Act (2010) was the result of the attempts to produce a single equality act which would bring together the major pieces of equality legislation in $\mathrm{GB}^{3}$. Under the Act, the following characteristics were regarded as protected: age, disability, gender reassignment, marital status, pregnancy and maternity, race, religion and belief, sex, and sexual orientation. The Act mirrored the equal treatment directives from the EU, evidencing the importance of the EU in influencing the equality agenda in the UK. Importantly, Part One of the Act concerned the duty on the public sector regarding socio-economic inequalities:

(1) An authority to which this section applies must, when making decisions of a strategic nature about how to exercise its functions, have due regard to the desirability of exercising them in a way that is designed to reduce the inequalities of outcome which result from socio-economic disadvantage.

The Equality Act 2010 was one of the last measures enacted by the Labour Government before they lost the 2010 election to the coalition government between the Conservative and Liberal Democrat (LibDem) parties. Hepple (2010) correctly predicted that the duty to public authorities regarding socio-economic equality would not be enforced by the incoming Conservative-LibDem Coalition Government. The incoming government did indeed drop this duty, declaring instead a preference for 'fairness', preferring equality of opportunity to equality of outcome. However, it was an important inclusion in the Act if only for symbolic reasons. It should be stressed that equality duties imposed on employers related to the public sector only and, as Hepple (2010) pointed out, over 80 per cent of workers are employed in the private sector. Furthermore, the delivery of public services was increasingly being outsourced to private companies, although it is important to note that the public duty to promote equality continues to apply to public 
bodies in contracting private services (McCrudden, 2011). Hepple (2010) argued that there was hence a risk that the positive duties included in the Equality Act 2010 could become ineffective and marginalised, and therefore, whilst the new Act was an important development, it was not the end of the struggle for equality, but an important beginning.

The Act did not extend to $\mathrm{NI}$, which, despite being a pathfinder to new ways to tackle inequality, appeared to be 'set to continue its own patchwork of antidiscrimination legislation rather than enact a single Act, because of disagreements within the powersharing government of that province' (ibid: 11).

The end of the first decade of the twenty-first century was marked by the drive for economic recovery after the shock of the financial crash and the implementation of austerity measures by the Conservative-LibDem coalition government. In response to these developments, a new array of social movements and a new focus for equality campaigners would arise - which was epitomised by the birth of the Occupy Movement in 2009 - in terms of the need to tackle economic inequality.

\section{The final curtain - is everyone equal now?}

It was perhaps tempting to draw the curtain under equality issues after the Equality Act 2010, which was hailed as a major step forward for positive equality duties. However, it should be remembered that the legislation relates to the public sector only. Even legislation aimed at addressing inequalities in pay among public and private sector employers has been criticised for not creating the kind of equality that is needed. This is particularly evident in the gender pay gap. The Equality Act 2010 (Gender Pay Gap Information) Regulations 2017 require all private and voluntary sector employers with 250 or more employees to publish information about their gender pay gap results. Similar requirements have been introduced for public sector employers. In 2019, the gender pay gap was estimated to be 17.3 per cent among all employees in the UK, whilst the overall hourly gender pay gap for median earnings for full-time employees in the UK was 8.9 per cent (ONS, 2019). Overall, the gender pay gap continues to be narrower in the UK in the public sector than the private sector (EHRC, 2018). It should be noted that there are issues with the methodology of calculating these estimates, given the wide variety of roles within particular industries and the difficulties of comparing roles and assessing their equivalence in terms of value to the organisation. Other issues affect the differences in pay such as the dual role women play as workers and caregivers, meaning that women were more likely to work part-time (and therefore have lower overall earnings than men). Erosaa et al. (2016) and Christofidesa et al. (2013) referred to the 'sticky floors' and 'glass ceilings' meaning that women were less likely to hold senior leadership positions. Levanon et al. (2009) argued that the feminisation of certain roles (e.g. nursing and teaching) meant that the pay for the entire industry where women are dominant was reduced.

Disparities in pay are not restricted to gender. For example, Coleman et al. (2013) highlight the 30 per cent pay gap between working age disabled people and non-disabled people, with disabled people more likely to be in lower-paid jobs. The TUC (2012) argued that, whilst unemployment among young people in general was of concern, the employment rate for young black men was half that of young white men. In contrast to the diversity approach among larger employers keen to show their equality credentials, van Wanrooy et al. (2013) argue that few employers in the private sector were carrying out equality monitoring or assessing pay practices on different groups of workers, and few had 
adopted measures to attract a diverse range of applicants. Hoque and Bacon (2014) contend that this situation could be improved by pressure from unions, which Manode and Brett (2015) argue was the missing piece of the jigsaw in terms of the ability to affect equality issues in the private sector. There is compelling evidence of the inverse relationship between trades union density and levels of inequality - namely, that a decline in union density is associated with a growth of inequality (Dromey, 2018).

The Equality Act 2010 replaced nine previous pieces of legislation (Hepple, 2010). It was also the driver for establishing the Public Sector Equality Duty (PSED), a key aim of which was to bring together the different equality duties that preceded it (race, disability and gender equality duties), to ensure that there should be no hierarchy of equality. The integration of the various strands of legislation has been welcomed as a way to harmonise the different duties and to address the intersectional nature of discrimination more effectively. It also allowed both employment and service delivery within public authorities to be covered by a single duty (Fredman, 2011). Nevertheless, concerns have been expressed regarding the integration of separate duties into one (Hepple, 2010), such as how successfully a single equality duty can simplify a complex area of law, as well as do justice to the different issues experienced between protected groups (for example, between disability and gender) as well as within protected groups (for example, between disabled men and women).

Conley and Wright (2015) argued that a limitation of the 2010 Act is that there is no equal pay provision or requirement to consult trades unions (which were specified by the Equality Act 2006). Furthermore, under the 2010 Act public authorities were no longer required to undertake equality impact assessments (tools to help public authorities to ensure that their policies, practices and decisions are fair and do not inadvertently discriminate against any protected group). Mitchell et al. (2015) argued that due to devolution there were now different levels of PSED across the regions, with England having a 'minimal' approach at one end of the spectrum and Wales having a detailed or prescriptive approach at the other end.

There have been calls for the Equality Act 2010 to be extended to the private sector from political parties in the UK. The experience in NI with the Fair Employment Act showed that it was possible to extend equality measures and monitoring requirements to the private sector. There has also been an increase in positive duties on the public sector with the Equality Act 2010, and Davies and Robison (2015) argued that Section 158 represented a potential shift towards equality of outcome, as it allows the use of positive discrimination where there is a 'tie-break' situation during public-sector recruitment and promotion. They point out that, while this is an important symbolic shift, the provision is voluntary and relates to the public sector only.

\section{Going forward - the sequel}

This review has provided strong evidence that the concept of equality means different things to different people, and has geographical, temporal and philosophical variations. Arguably, UK legislators have favoured an approach based on the concept of equality of opportunity (Bagilhole, 2009). Consequently, formal consultations prioritise this political conception of equality, as do frameworks designed to measure government performance such as outcomes based accountability mechanisms (Gray and Birrell, 2018). 
Whilst NI may once have led the way in terms of equality legislation, the introduction of the Equality Act 2010 in GB left NI behind in a game of equality leapfrog. At the end of a transitionary period in 2020, the UK can develop separate and independent policies in various social policy areas including equality, without the need to comply with EU law. We do not know what kind of Brexit will be finally reached and, in the absence of a full equality impact assessment (Hepburn, 2020), we do not know the potential impact on different groups. However, predictions based on a range of scenarios (ibid) suggest a 'hard' Brexit would result in a loss of equality rights and further weakening of protections; a 'softer' Brexit would see some rights lost; and a 'no-deal' Brexit was more likely to bring a loss of rights, social disorder, economic chaos and community tension. Hence, the equality 'leapfrog' analogy between GB and NI could become a game of backward leapfrog.

Equality was the cornerstone of the NI peace settlement (McLaughlin, 2003) and equality-related issues played an important part in the collapse of the devolved government in 2017 (Guardian, 2019). The new decade saw progressive steps being made in NI with same-sex marriage legalised in January 2020 and abortion decriminalised in October 2019 with abortion services due to be provided from April 2020. NI now faces a new future with the restoration of devolution in January 2020. This was accompanied by the New Decade New Approach deal (NIO, 2020), which has raised expectations that equality gaps which exist between $\mathrm{GB}$ and $\mathrm{NI}$ will be addressed soon. Any weakening of British equality and human rights legislation would significantly limit Northern Ireland's chances of 'catching up' and, ultimately, would put an already fragile process of peace building at risk. For example, the NI Act 1998, together with the Human Rights Act 1998 (which incorporates the ECHR), forms the foundation of the Good Friday/Belfast Agreement. Any measure to dismantle that architecture poses risks to the Agreement's stability and causes anxiety for many in NI (Harvey, 2015a). If, as Harvey (2015b) notes, no government likes to be embarrassed internationally, only time will tell whether the international dimensions of the Agreement can help keep governmental minds focused on their responsibilities and commitment to supporting a shared society based on equality and human rights.

\section{Acknowledgements}

This work was supported by the Faculty of Arts, Humanities and Social Sciences Research Initiatives Fund, Queen's University Belfast

\section{Notes}

1 The United Kingdom comprises Great Britain (England, Scotland and Wales) and Northern Ireland.

2 Young (2000) argues that there are two forms of political exclusion in terms of participation in legal decision-making which act as a barrier to more egalitarian politics: external exclusion where individuals and groups are absent from decision-making forums or are dominated by others when included; and internal exclusion where even when meaningfully included, differences in styles of expression and unfamiliarity with legal language renders their inclusion meaningless.

3 Equal Pay Act 1970, the Sex Discrimination Act 1975, the Race Relations Act 1976, the Disability Discrimination Act 1995 and three major statutory instruments which prohibit discrimination in employment on the grounds of sexual orientation, religion or belief and age. 


\section{References}

Bagilhole, B. (2009) Understanding Equal Opportunity and Diversity: The Social Differentiations, Bristol: Policy Press.

Baker, J., Lynch, K., Cantillon, S. and Walsh, J. (2004) Equality: From Theory to Action, Palgrave Macmillan. Brammer, S., Millington, A. and Pavelin, S. (2009) 'Corporate reputation and women on the board', British Journal of Management, 20, 17-29.

Chaney, P. (2011) 'Education, equality and human rights: exploring the impact of devolution in the UK', Critical Social Policy, 31, 3, 431-53.

Christofidesa, L., Polycarpoua, A. and Vrachimis, K. (2013) 'Gender wage gaps, 'sticky floors' and 'glass ceilings' in Europe', Labour Economics, 21, 86-102.

Coleman, N., Sykes, W. and Groom, C. (2013) Barriers to Employment and Unfair Treatment at Work: A Quantitative Analysis of Disabled People's Experiences, London: Equality and Human Rights Commission.

Conley, H. and Wright, T. (2015) 'Making reflexive legislation work: stakeholder engagement and public procurement in the public sector equality duty', in Equality and Diversity Forum and EDF Research Network, Beyond 2015, London: Equality and Diversity Forum, 54-64.

Cunningham, S. (1992) 'The Development of equal opportunities theory and practice in the European Community', Policy and Politics, 20, 3, 177-89.

Davies, C. and Robison, M. (2015) 'Shifting the starting blocks: an exploration of the impact of positive action in the UK', in Equality and Diversity Forum and EDF Research Network, Beyond 2015, London: Equality and Diversity Forum, 65-76.

Davies, W. (2017) The Limits of Neoliberalism, London: Sage.

Department for Communities and Local Government [DCLG] (2007) A Framework for Fairness: Proposals for a Single Equality Bill for Great Britain, London: DCLG.

Department of Trade and Industry (DTI) (2002) Equality and Diversity: Making it Happen, London: DTI. Department of Trade and Industry (DTI) (2003) Press Release P/2003/537, DTI 29 October.

Department of Trade and Industry (DTI) (2004) Fairness for All: A New Commission for Equality and Human Rights, Norwich: The Stationery Office.

Department of Trade and Industry and Department of Constitutional Affairs (DTI and DCA) (2004) White Paper on Equality and Human Rights: A New Framework for Britain, London: DTI and DCA.

Donnelly, C. and Osborne, R. D. (2005) 'Devolution, Social policy and education: some observations from Northern Ireland', Social Policy and Society, 4, 2, 147-56.

Dromey, J. (2018) Power to the People: How Stronger Unions can Deliver Economic Justice, Discussion Paper, IPPR Commission on Economic Justice, London: Institute for Public Policy Research.

Equalities Review (2007) Fairness and Freedom: The Final Report of the Equalities Review, London: Equalities Review.

Equality and Human Rights Commission (EHRC) (2018) Progress on Socio-Economic Rights in Great Britain: Update Report on Great Britain's Implementation of the International Covenant on Economic, Social and Cultural Rights, London: EHRC.

Erosaa, A., Fustera, L. and Restuccia, D. (2016) 'A quantitative theory of the gender gap in wages', European Economic Review, 85, 165-87.

Fredman, S. (2002) Discrimination Law, Oxford: Oxford University Press.

Fredman, S. (2011) 'The Public Sector Equality Duty', Industrial Law Journal, 40, 4, 404-27.

Gedalof, I. (2013) 'Sameness and difference in government equality talk', Ethnic and Racial Studies, 36, 1, $117-35$.

Goodwin, M. and Heath, O. (2016) Brexit vote Explained: Poverty, Low Skills and Lack of Opportunities, York: Joseph Rowntree Foundation.

Gormley-Heenan, C. and Aughey, A. (2017) 'Northern Ireland and Brexit: three effects on 'the border in the mind", The British Journal of Politics and International Relations, 19, 3, 497-511. 
Government Equalities Office (2008) Equality Bill: Government Response to the Consultation, Norwich: The Stationery Office.

Gray, A. and Birrell, D. (2018) 'Outcomes-based approaches and the devolved administrations', Social Policy Review, 30, 67-86.

The Guardian (2019) Timeline of Northern Ireland's Power-Sharing Crisis, 26 April, https://www.theguardian. com/politics/2019/apr/26/northern-ireland-power-sharing-stormont-crisis-timeline [accessed 27.05.2020].

Harvey, C. (2015a) 'HRA watch: reform, repeal, replace? Rights in a fractured union' UK Constitutional Law Association Blog, 1 June, https://ukconstitutionallaw.org/2015/06/01/hra-watch-reform-repealreplace-colin-harvey-rights-in-a-fractured-union/ [accessed 21.11.2020].

Harvey, C. (2015b) Rights, Equality and Social Justice in a Cold Climate, http://rightsni.org/2015/06/rightsequality-and-social-justice-in-a-cold-climate/ [accessed 21.11.2020].

Harvey, C. and Spencer, S. (2011) Equality and Human Rights Commissions in the UK and Ireland: Challenges and Opportunities Compared, School of Law, Queen's University Belfast and Centre on Migration, Policy and Society, University of Oxford.

Harvey, D. (2005) A Brief History of Neoliberalism, Oxford: Oxford University Press.

Hayward, K. and Mitchell, C. (2003) 'Discourses of equality in post-agreement Northern Ireland', Contemporary Politics, 9, 293-312.

Hepburn, E. (2020) Social and Equality Impacts of Brexit, Edinburgh: The Scottish Government.

Hepple, B. (2010) 'The new single equality act in Britain', Equality Rights Review, 5, 11-24.

Hill, M., McAuley, C., McLaughlin, E. and Porter, F. (2005) Eighty Years of Talking about Equality in Northern Ireland: a History of Equality Discourses and Practices, Poverty and Social Inclusion, Working Paper 5, Belfast: Equality and Social Inclusion in Ireland.

Home Office (2001) Community Cohesion: A Report of the Independent Review Team, London: Home Office.

Home Office (2004) Strength in Diversity: Towards a Community Cohesion and Racial Equality Strategy, London: Home Office Community Directorate.

Hoque, K. and Bacon, N. (2014) 'Unions, joint regulation and workplace equality policy and practice in Britain: evidence from the 2004 Workplace Employment Relations Survey, Work, Employment and Society, 28, 2, 265-84.

Joseph, K. and Sumption, J. (1979) Equality, London: John Murray.

Joseph, M. (2014) Debt to Society: Accounting for Life Under Capitalism, Minneapolis: University of Minnesota Press.

Kaufmann, E. (2016) It's NOT the Economy Stupid: Brexit is a Story of Personal Values, https://blogs.Ise.ac. uk/politicsandpolicy/personal-values-brexit-vote/ [accessed 21.11.2020].

Levanon, A., England, P. and Allison, P. (2009) 'Occupational feminization and pay: assessing causal dynamics using 1950-2000 U.S. Census Data, Social Forces, 88, 2, 865-91.

Liswood, L. A. (2010) The Loudest Duck: Moving Beyond Diversity While Embracing Differences to Achieve Success at Work, Hoboken: John Wiley and Sons.

Mackay, F. and Bilton, K. (2000) Learning from Experience: Lessons in Mainstreaming Equal Opportunities, Edinburgh: University of Edinburgh.

Manode, J. and Brett, S. (2015) 'Union equality representatives: the missing piece of the jigsaw?', in Equality and Diversity Forum and EDF Research Network, Beyond 2015, London: Equality and Diversity Forum, 196-206.

Marshall, J. (1994) Women Managers: Travellers in a Male World, Chichester: Wiley.

McCrudden, C. (1998) 'Mainstreaming Equality in the Governance of Northern Ireland', Fordham International Law Journal, 22, 4, 1696-775.

McCrudden, C. (2007) 'Equality legislation and reflexive regulation: a response to the Discrimination Law Review's consultative paper', Industrial Law Journal, 36, 3, 255-66. 
McCrudden, C. (2011) 'Procurement and the public sector duty: lessons for the implementation of the Equality Act 2010 from Northern Ireland?', International Journal of Discrimination and the Law, 11, 12, 85-98.

McKittrick, D. and McVea, D. (2010) Making Sense of the Troubles: A History of the NI Conflict, London: Penguin.

McLaughlin, E. (2003) 'Equality and equity policy', in M. Hawesworth and M. Kogan (eds.), Encyclopedia of World Government and Politics, 2nd ed., London, Routledge.

McLaughlin, E. (2007) 'From negative to positive equality duties: the development and constitutionalisation of equality provisions in the UK', Social Policy and Society, 6, 1, 111-21.

Mitchell, M., Bennett, C. and Hudson, R. (2015) Public Sector Duty Implementation Models: Scoping Paper, Dublin: Irish Human Rights and Equality Commission.

Mooney, G. and Scott, G. (2016) 'Welfare, equality and social justice: Scottish independence and the dominant imaginings of the 'New' Scotland', Ethics and Social Welfare, 10, 3, 239-51.

Northern Ireland Office (NIO) (2020) New Deal New Approach, Belfast: Northern Ireland Office.

O'Cinneide, C. (2003) Taking Equal Opportunities Seriously: The Extension of Positive Duties to Promote Equality, London: The Equality and Diversity Forum.

Office for National Statistics (ONS) (2019) Gender Pay Gap in the UK: 2019, London: ONS.

Ozbilgin, M. and Tatli, A. (2011) 'Mapping out the field of equality and diversity: rise of individualism and voluntarism', Human Relations, 64, 9, 1229-53.

Parekh, B. (1992) 'A case for positive discrimination', in B. Hepple and E. M. Szyszak (eds.), Discrimination: The Limits of Law, London: Mansell Publishing, 261-80

Pringle, J. K. (2008) 'Gender in management: theorizing gender as heterogender', British Journal of Management, 19, 1, 110-9.

Rawls, J. (1971) A Theory of Justice, Oxford: Oxford University Press.

Rawls, J. (1999) The Law of Peoples, Cambridge, MA: Harvard University Press.

Robertson, D. (2015) 'The long road to inclusivity', in Equality and Diversity Forum and EDF Research Network, Beyond 2015, London: Equality and Diversity Forum, 173-82.

Rose, N. (1999) Powers of Freedom: Reframing Political Thought, New York: Cambridge University Press.

Schrecker, T. and Bambra, C. (2015) How Politics Made Us Sick: Neoliberal Epidemics, Basingstoke: Palgrave Macmillan.

Sen, A. (1982) Choice, Welfare and Measurement, Cambridge, MA: Harvard University Press.

Tatli, A. (2011) 'A multi-layered exploration of the diversity management field: diversity discourses, practices and practitioners in the UK', British Journal of Management, 22, 238-53.

Tatli, A. and Ozbilgin, M. (2009) 'Understanding diversity managers' role in organizational change', Canadian Journal of Administrative Sciences, 26, 244-58.

Townsend, P. (1979) Poverty in the United Kingdom, Harmondsworth: Penguin Books.

TUC (2012) Youth, Unemployment and Ethnicity, London: Trades Union Congress.

van Wanrooy, B., Bewley, H., Bryson, A., Forth, J., Freeth, S., Stokes, L. and Wood, S. (2013) The 2011 Workplace Employment Relations Study: First Findings, London: BIS.

Young, I. M. (2000) Inclusion and Democracy, Oxford: Oxford University Press. 